\title{
Advanced Research in Solar Energy Storage
}

Werner Luft

January 1983

To be presented at the 2nd BHRA Engineering International Conference on Energy Storage:

Energy Storage for Energy Management Stratford-upon-Avon, England

24-26 May 1983

Prepared Under Task No. 1297.00

WPA No. 348-82

Solar Energy Research Institute

A Division of Midwest Research Institute

1617 Cole Boulevard

Golden, Colorado 80401

Prepared for the

U.S. Department of Energy

Contract No. EG-77-C-01-4042 
Printed in the United States of America

Available from:

National Technical Information Service

U.S. Department of Commerce

5285 Port Royal Road

Springfield, VA 22161

Price:

Microfiche $\$ 3.00$

Printed Copy $\$ 4.00$

\section{NOTICE}

This report was prepared as an account of work sponsored by the United States Government. Neither the United States nor the United States Department of Energy, nor any of their employees, nor any of their contractors, subcontractors, or their employees, makes any warranty, express or implied, or assumes any legal liability or responsibility for the accuracy, completeness or usefulness of any information, apparatus, product or process disclosed, or represents that its use would not infringe privately owned rights. 


\section{ADVANCED RESRARCE IN SOLAR ENBRGY STORAGE *}

\section{Werner Luft}

Solar Energy Research Institute

1617 Cole Boulevard

Golden, Colorado 80401

\section{Summary}

This paper gives an overview of the Solar Energy Storage Program at the Solar Energy Research Institute. The program provides research, systems analyses, and economic assessments of thermal and thermochemical energy storage and transport. Current activities include experimental research into very tigh temperature (above $800^{\circ} \mathrm{C}$ ) thermal energy storage and assessment of novel thermochemical energy storage and transport systems.

The applications for such high-temperature storage are thermochemical processes, solar thermalelectric power generation, cogeneration of heat and electricity, industrial process heat, and thermally regenerative electrochemical systems.

The research results for five higth-temperature thermal energy storage technologies and two thermochemical systems are described.

This work was funded by the U.S. Department of Energy, Energy Storage Division under contract EG-77-C-0l-4042. 


\section{ITTRODOCTIOK}

The overall objective of the solar energy storage program at the Solar Energy Research Institute is to develop cost-effective advanced thermal energy storage and transport technologies for use in solar-powered systems to make the costs of such systems competitive with fossil-fuel-powered systems in the 1990-20l0 time frame. The emphasis of the program is on thermal energy storage for solar thermal power and process heat applications and on thermal energy transport. Our research was redirected in 1982 towards high-temperature (above $800^{\circ} \mathrm{C}$ ) storage and associated directcontact heat exchangers as a result of value and cost analyses performed in prior years (Refs. $l, 2,3$ ) and completed in 1982. We also identified in 1982 new areas for thermochemical energy storage and transport having considerably greater energy densities then previously studied systems.

The rationale for concentrating the research on storage at temperatures above $800^{\circ} \mathrm{C}$ is that $(l)$ high-temperature storage provides a good potential for significant conservation of premium fossil fuels; (2) systems below $600^{\circ} \mathrm{C}$ are already fairly well developed (3) higt-temperature storage represents higt-risk, high payoff research not likely to be sponsored by industry; and (4) high temperature is the direction of the solar central receiver work within the United States Department of Energy, Solar Thermal Technology Division for improved energy conversion efficiency and our stor age program is in support of their work. The higt-temperature thermal storage systems offer the potential for $30 \%$ cost reduction for solar hytrogen production (Ref. 4) and for $15 \%$ cost reduction for solar electric power generation (Ref. 5).

The applications for high-temperature (above $800^{\circ} \mathrm{C}$ ) energy storage are (1) thermochemical processes, such as fuels and chemicals production; (2) solar thermal-electric power generation topping cycles using turbine equipm ent; (3) cogeneration of heat and electricity; (4) industrial process heat, such as cement and glass production and petroleum refining; and (5) thermally regenerative electrochemical systems.

\section{SYSTEM ANAL YSES}

The choice of storage technologies subjected to advanced research is based on value and cost analyses. The value of thermal storage in solar thermal applications is based on the cost for fossil-fuelpowered beckup systems using either natural gas or residual oil, using medium to high fuel cost escalation scenarios. Typically, the value calculations apply to the 1990 time frame. Such value calculations have been made both for electric power generation applications (Ref. l) and for industrial process heat applications (Ref. 2). The value provides cost goals Storage concepts are then assessed relative to these cost goals using a consistent costing methodology taking into account the performance of each system. Both value and cost for storage are a function of storage capacity. Generally the value and cost decrease with increasing storage capacity (storage duration) but not necessarily at the same rate.

The costs for a large number of advanced storage concepts have been estimated. Some of these systems for which the original cost estimates compared favorably with the value have been selected for research either in-house by the Solar Energy Research Institute or under subcontracts. This research includes concepts having storage temperatures ranging from $385^{\circ} \mathrm{C}$ to $1450^{\circ} \mathrm{C}$. The storage technologies covered by this research are shown in Table l. The cost data are the latest projections based on the costing methodology described in Ref. 3. In some cases these projections are considerably higher than the original projections made when the research was initiated. This fact accounts for systems being investigated that have value-to-cost ratios below unity.

The status of the research for these five systems is described in the next section.

\section{ADVANCED RESBARCH IN THERMAL ENERGY STORAGE}

\subsection{Molten slag (Ref. 6)}

Analysis, conceptual design, and experimental work was conducted for very high temperature $\left(1400^{\circ} \mathrm{C}\right)$ thermal energy storage for a $23-\mathrm{MW}$, solar energy system including a central receiver and a Brayton-cycle turbine, for a lo-iMW e electric power application.

The heat transfer and storage medium is a glassy slag. Beads of slag are melted by directabsorption heat exchange in the solar central receiver. The molten slag is stored at $1380^{\circ} \mathrm{C}$ in ref ractory-lined storage vessel. Slag pumps use sliding valves and air pressure $\left[2.5 \times 10^{6} \mathrm{~N} / \mathrm{m}^{2}\right.$ (25 atm)] to move the slag from the storage tank to the direct-contact heat exchanger. Sensible heat is extracted from the molten slag in a direct-contact heat exchanger in which the slag is sprayed through a high-pressure counter-flowing working gas. The $1230^{\circ} \mathrm{C}$ hot gas operates a regenerative Brayton gas turbine with $43 \%$ efficiency. The solidified slag droplets at $712^{\circ} \mathrm{C}$ are returned to the central receiver to repeat the cycle. 
Table 1. Valwo-to-Cost Ratio for Advanesd Thermal Storage Concepts with Appopriafe Advineed Certral Receivers

\begin{tabular}{lccccc}
\hline $\begin{array}{l}\text { Storage } \\
\text { Technology }\end{array}$ & $\begin{array}{c}\text { Storage } \\
\text { Capacity } \\
\text { (hours) }\end{array}$ & Application & $\begin{array}{c}\text { Value } \\
\left(\$ / \mathrm{kWh}_{\mathrm{t}}\right)\end{array}$ & $\begin{array}{c}\text { Cost } \\
\left(\$ / \mathrm{kWh}_{\mathrm{t}}\right)\end{array}$ & $\begin{array}{c}\text { Value/Cost } \\
\text { Ratio }\end{array}$ \\
\hline Molten slag & 6 & $\begin{array}{c}\text { electric } \\
\text { power }\end{array}$ & $20-25$ & 28 & $0.7-0.9$ \\
$\begin{array}{c}\text { High temperature } \\
\text { molten salt }\end{array}$ & 6 & $\begin{array}{c}\text { electric } \\
\text { power }\end{array}$ & 25 & 5.0 & 5 \\
$\begin{array}{c}\text { Draw salt/air rock } \\
\begin{array}{c}\text { process } \\
\text { heat }\end{array}\end{array}$ & 48 & $10-20$ & 6.7 & $1.5-3.0$ \\
$\begin{array}{c}\text { Phase-change salt/ } \\
\text { ceramic pellets }\end{array}$ & $1-15$ & $\begin{array}{c}\text { process } \\
\text { heat }\end{array}$ & 20 & $25-30$ & $0.7-0.8$ \\
$\begin{array}{c}\text { MetaVphase-change } \\
\text { salt }\end{array}$ & $1-15$ & $\begin{array}{c}\text { process } \\
\text { heat }\end{array}$ & 20 & 10 & 2 \\
\hline
\end{tabular}

QWith direct-contact heat exchanger.

The objective of the work was to demonstrate the technical and economic feasibility of this system concept. The scope of the work included (1) an investigation of the thermophysical and chemical properties of candidate thermal energy storage media and containment vessel materials, (2) analysis of heating and melting of the storage medium in the solar central receiver, (3) study of slag handling and transport including design of slag pump and bead transport system, (4) development of droplet heat exchanger model, (5) conceptual design of the thermal storage subsystem, and (6) determination of capitah operating, and maintenance costs using a prescribed methodology and specifc economic parameters.

Slag selection was made on the basis of low viscosity $(<\mathrm{Pa} \mathrm{s})$ at the melting point, melting point around $1300^{\circ} \mathrm{C}$, relatively high surface tension, low vapor pressure, stability at high temperature, and high heat capacity. The selected material, $50 \% \mathrm{SiO}_{2}, 30 \% \mathrm{CaO}$, and $20 \% \mathrm{MgO}$, has a liquidus temperature of $1360^{\circ} \mathrm{C}$, viscosity of $0.51 \mathrm{~Pa} \mathrm{~s}$ at $1400^{\circ} \mathrm{C}^{2}$, density of $2.9 \mathrm{~g} / \mathrm{cm}^{3}$, surface tension of $0.42 \mathrm{~N} / \mathrm{m}$ at $1400^{\circ} \mathrm{C}$, specific heat of $1.22 \mathrm{~kJ} / \mathrm{kg} \mathrm{K}$, and a partial pressure for SiO at $1360^{\circ} \mathrm{C}$ of 3.5 $\mathrm{mPa}$.

The amount of slag stored depends on the required storage time and ranges from $9.6 \times 10^{4}$ to $4.6 \times 10^{6} \mathrm{~kg}$ for $\mathrm{l}$ to 48 hours of storage time. The cost of the slag is very low in comparison with other storage media, except rocks. But rocks cannot withstand the high temperature of this system.

The selected insulation for the storage tank and slag pumps is fused-cast alpha-alumina (99.3\% $\mathrm{Al}_{2} \mathrm{O}_{3}$ ) blocks having high resistance to basic slags. The corrosion rate at the melt line at $1380^{\circ} \mathrm{C}$ is about $0.2 \mathrm{~mm}$ per day.

The doplet heat exchanger ( $6.5 \mathrm{~m}$ high and $3 \mathrm{~m}$ in diameter) is lined with graphite blocks. Pressurized slag is injected via a molybdenum injector plate and forms $1-\mathrm{mm}$ droplets that solidify before hitting the bottom of the heat exchanger at $710^{\circ} \mathrm{C}$. The baseline design uses $2 \times 10^{5} \mathrm{~N} / \mathrm{m}^{2}$ $(20-a t m)$ argon as the working gas. Experiments on the liquid injection system were performed and droplet farmation (in the range of 1 to $3 \mathrm{~mm}$ of diameter) was achieved.

The economic analysis showed that the costliest items are the fused-cast alphe-alumina blocks for tanks, pumps, and pipes; the slag pumps; and the droplet heat exchanger. The capital investment costs range from $\$ 239 / \mathrm{kWh}$ for I hour of storage capacity to $\$ 22 / \mathrm{kWh}$ at 48 hours of storage capacity. In comparison with other thermal storage technologies for electric power production, the molten slag system is more costly at all storage capacities. Thus, any future work must be directed to find lower-cost insulation materials and to reduce the cast of the slag pumps and droplet heat exchanger. The feasibility of the direct-contact central receiver also needs to be established through additional work. 


\subsection{Eigh-temperature molten salt (Ref. 4)}

The objective of this project is to research key issues in advanced, high-temperature molten salt thermal storage. Systems analyses at SERI have shown that high-temperature $\left(800^{\circ}\right.$ to $\left.1100^{\circ} \mathrm{C}\right)$ molten salts are potentially attractive both as receiver coolants and as storage media, but at high temperatures they may require direct-contact heat exchange, new kinds of storage tank insulation, and new ways to maintain a sharp thermocline (Ref. 4). The salts could be sodium hydroxide, car bonates, or chlorides. They are all inexpensive and stable up to $1100^{\circ} \mathrm{C}$. Applications for solar thermal-electric power generation using combined energy conversion cycles have been identified for maximum temperatures ranging from $900^{\circ}$ to $1100^{\circ} \mathrm{C}$. A multiphase project is being conducted. Initially, the $900^{\circ} \mathrm{C}$ case is being explored since it has lower rislg the $1100^{\circ} \mathrm{C}$ case will be emphasized in the latter phases.

The problems with such high-temperature salt storage are how to contain the hot salt, how to achieve high storage efficiency, and how to accomplish the containment and high efficiency in a cost-effective manner.

The approach to solving these problems is to use a single-tank thermocline storage subsystem, submerged internal insulation, and an insulating platform floating at the thermocline between the hot and cold salt.

This approach allows ue of a low-cost carbon steel container at $1100^{\circ} \mathrm{C}$ molten salt temperature because of the internal insulation. The design is such that at a $2 \%$ daily heat loss, the temperature drop through the insulation gives $350^{\circ} \mathrm{C}$ at the tank wall. The internal insulation is porous to reduce the insulation weight and cost. Trapped molten salt acts as insulation in its own right. There are a number of potential mechanisms that tend to degrade a thermocline (Ref. 7). At the high temperatures involved here, there is also a radiation exchange from the hot salt and wall instr lation at the top of the tank to the cooler salt at the bottom. Many of these degradation mechanisms are eliminated or reduced by the use of a floating insulating platform between the hot and cool salt regions. The platform ensures a sharp thermocline and thus high storage efficiency.

During 1982, two of the key issues were addressed an insulating noating platform (raft) and materials compatibility. The raft must follow the interface of the hot and cold fluids at all states of charge and discharge. Such a device has not previously been demonstrated in practice. Stability of the raft must be ensured. Water was used as the medium for the precursor experiments to mir imize cost. Later in the program a raft will be tested in molten salt.

The structural and insulating materials must be compatible with the molten salt since they are in direct contact. Three mechanisms could cause incompatibility: chemical reactions, corrosion, and solution. The need for a long life and minimal replacement costs permits only very low rates of material degradation. Some candidate materials have been identified as promising. Research is continuing to evaluate these and to identify other low-cost materials (Ref. 5).

\subsection{Drew selt/air rock (Ref. 8)}

Research was initiated in 1982 for molten nitrate salt storage $550^{\circ} \mathrm{C}$ in combination with air/rock storage, where the heat is transf erred from the molten salt to the rock using an air loop. The application for this technology is industrial process heat. The work involves evaluation of the heat transfer coefficient between the molten salt and air in a packed column heat exchanger.

The objective of the research is to reduce the heat-transf er-related costs of thermal energy storage systems. Direct-contact heat exchangers have cost advantages over conventional fin-tube indireet heat exchangers and would be used to couple short-term molten salt storage to longer-term air/rock storage to obtain long-duration storage.

Air/rock storage systems have been identified as a promising high-capacity-factor storage alternative for molten nitrate salt receivers. A large component of the cost is the heat exchanger needed to transfer energy to and from the air. The cost of such heat exchangers can potentially be reduced by approximately two-thirds if they are replaced with packed columns in which air and molten salt are in direct contact. Direct-contact devices are also advantageous because they are not subject to fouling.

A second we for such direct-contact exchangers would be in very high-temperature $\left(800^{\circ} \mathrm{C}\right.$ to $\left.1100^{\circ} \mathrm{C}\right)$ molten salt receiver/storage systems using molten sodium hydroxide or carbonate salts. Analyses have shown that these systems can produce electricity for $12 \%$ lower cost than nitrate salt systems (Ref. 5). At these high temperatures, the direct-contact exchangers would compete even more favorably with conventional heat exchangers because conventional exchangers would need ceramic tubes, which are expensive and difficult to fabricate. The cost differences are so great that they have a direct bearing on the system practicality (Ref. 9). 
An experimental loop has been constructed to develop methods for predicting the performance of direct-contact heat exchangers, and to test various packing designs. Such testing will be conducted in 1983.

\subsection{Phese-change salt/ceramic pellets (Ref. 10)}

Experimental and anelytical investigations were made for energy storage in conjunction with solar central receiver systems using air as a working medium and a Brayton energy conversion cycle operating at $700^{\circ}$ to $900^{\circ} \mathrm{C}$ for electric power generation. An alternate application is for industrial process heat.

The energy storage is achieved using direct-contact heat exchange between air and pellets of high heat capacity, consisting of a mixture of phase-change salts within a porous ceramic matrix. The salt changes phase from solid to liquid over the storage operating temperature range. The molten salt is held within the void space in the ceramic body primarily by capillary forces.

The work so far has centered on fabrication techniques and material stability of the pellets. The mechanical properties of the pellets have been tested, and laboratory experiments have been conducted to evaluate the charge/discharge characteristics of the pellets.

From 10 candidate salt mixtures, a carbonate salt with a composition of $48 \mathrm{wt} \% \mathrm{Na}_{2} \mathrm{CO}_{3}$ and 52 wt $\% \mathrm{BaCO}_{3}$, and with a melting point of $713^{\circ} \mathrm{C}$ and a heat of fusion of $185 \mathrm{~kJ} / \mathrm{kg}$, was selected for proof-of-concept testing and for further development. Both $\mathrm{MgO}$ and NaAlO, were evaluated as ceramic support materials, and the magnesium oxide was selected for proof-of-concept testing.

A composite powder of approximately 60 vol $\%$ (or 51 wt $\%$ ) salt and 40 vol $\%$ magnesium oxide was prepared by spray-drying of aqueous slykries. The powder was consolidated through die-pressing into cylindrical high-density $\left(1.8 \mathrm{~g} / \mathrm{cm}^{3}\right)$ pellets of approximately $13 \mathrm{~mm}$ diameter and $10 \mathrm{~mm}$ height. Sintering at $1100^{\circ} \mathrm{C}$ for 2 hours (or $1150{ }^{\circ} \mathrm{C}$ for 1 hour) yielded pellets of $87 \%$ theoretical density at room temperature. The pellets were evaluated for salt retention capability, thermal cycling response, and packed-bed behavior. Exposure of sintered pellets to various temperatures $\left(800-850^{\circ} \mathrm{C}\right)$ and durations (50-1 i hours) gave weight losses ranging from $1 \%$ to $18 \%$.

A laboratory-scale, direct-contact heat exchanger was used to evaluate the performance of a randomly packed bed of pellets. A maximum heat flux of $5.2 \mathrm{~kW} / \mathrm{m}^{2}$ was achieved for an air flow of $5.7 \mathrm{~m}^{3} / \mathrm{h}$ in an experiment in which approximately $\mathrm{l} \mathrm{kg}$ of pellets with a volume packing density of $58 \%$ and a heat transfer surface of $0.26 \mathrm{~m}^{2}$ were heated to $815^{\circ} \mathrm{C}$ and cooled to $615^{\circ} \mathrm{C}$, giving a change in enthalpy of $0.25 \mathrm{MJ}$, for 17 cycles over a 398-hour period of operation.

An economic analysis showed that the capital investment for a 2160-MWh imately $\$ 30 / \mathbf{k W h}$ of thermal storage capacity using carbonate salt-magnesium oxide pellets. Although this cost is higher than the value at 6 hours of storage capacity, the value-to-cost ratio for smaller storage capacities would exceed unity. The cost of $\$ 30 / \mathrm{kWh}_{\mathrm{t}}$ also represents a considerable reduction as compared to the cost for thermal energy storage in ceramic bricks.

\subsection{Metal/phase-change salt}

The final system investigated in iolves hot salt storage for a solar central receiver system using water/steam as a heat transfer medium. The system is shown in Fig. l. It uses a two-stage storage subsystem. The first stage uses latent-heat storage and the second stage, sensible-heat storage. The application is for industrial process heat steam at $482^{\circ} \mathrm{C}, 3.1 \mathrm{MPa}$. Our work involves an experimental investigation of the heat transf er and operation of the first-stage storage.

In this system, molten droplets of salt at $292^{\circ} \mathrm{C}$ from the liquid-salt storage tank are injected at the bottom of a container for the liquid metal ( $\mathrm{Pb} / \mathrm{Bi}$ ) carrier nuid. As the lighter-weight molten salt droplets rise through the cooler liquid metal, they release their heat of fusion and solidify individually. The solidified salt is pushed over the edge of the heat-transfer container and falls to the bottom of the salt storage tank where it is melted again by a spray of $321^{\circ} \mathrm{C}$ salt from the first-stage water/steam-to-salt heat exchanger in the central receiver loop. The liquid metal is pumped to a storage tank and to the first-stage heat exchanger at the user side.

The temperatures shown in Fig. 1 and mentioned above apply to a draw-salt system. However, it was found that the draw salt oxidizes the lead-bismuth alloy. Thus, alternative phase-change salt/metal systems are presently being investigated. One possibility is sodium hydroxide with $\mathrm{Pb} / \mathrm{Bi}$. Another possibility is to use an oil instead of the metal.

The experimental equipment has been built and heat transfer measurements will be conducted in 1983. 
1 st Stage: Latent-Heat Storage 2nd Stage: Sensible-Heat Storage

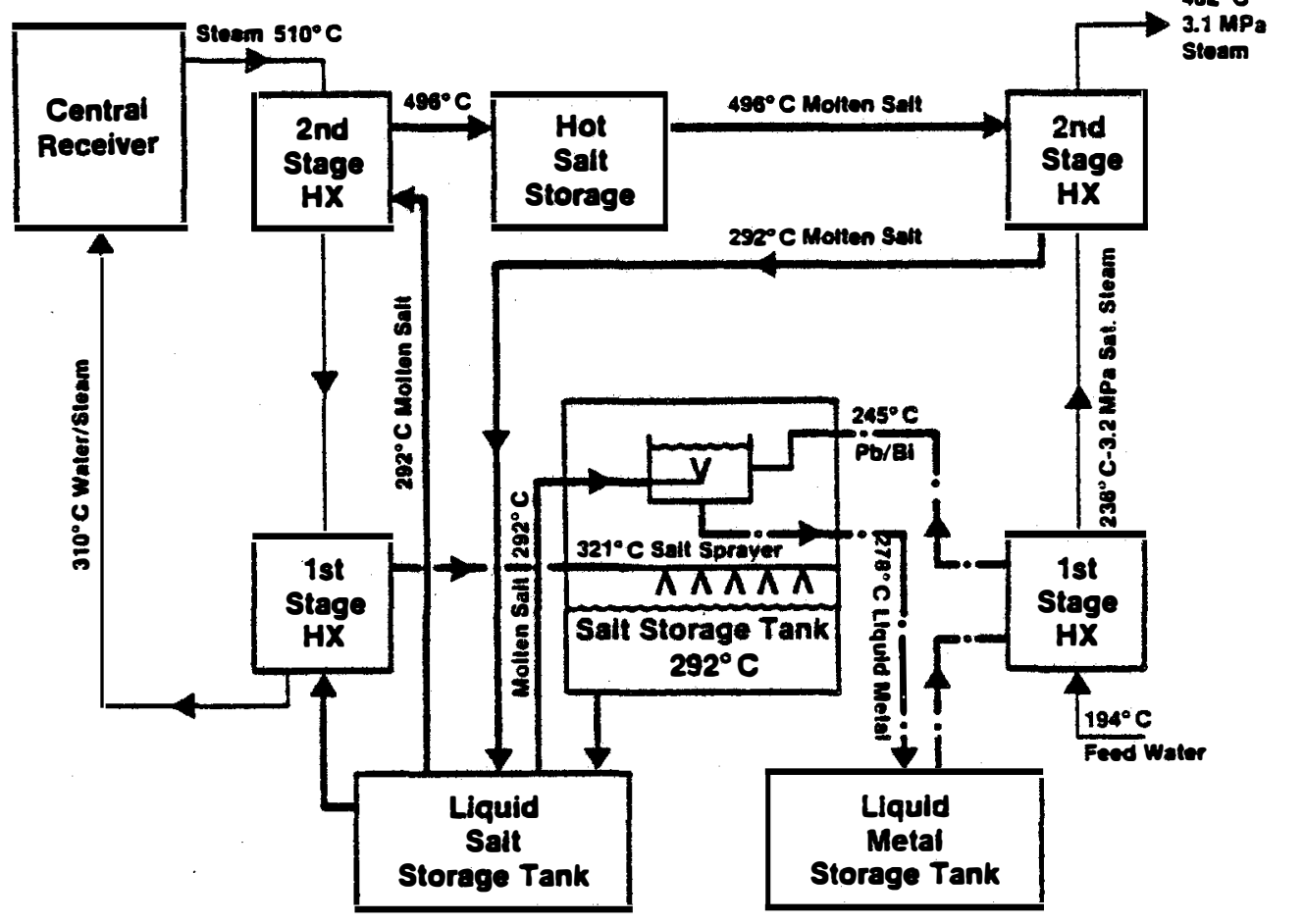

Fig. 1. Salt/Metal Heat Buinnge for a Fater/Sream Solar Central Receiver System Using Two Stages of Thermal Storiges, Latent Bent and Sencible Beat

\section{THERMOCHEMICAL ENERGY STORAGE AND TRANSPORT}

Two areas of potentially cost-effective thermochemical energy storage and transport oi higr:quality thermal energy have been identified based upon extensive assessments: (1) carbon dioxide splitting for carbon monoxide transport, and (2) thermochemical heat pumping using the strong exothermic reaction of molten anhydrous materials with water.

Previous thermochemical transport systems that were assessed all had energy densities of 2.7 to 3.9 $\mathrm{MJ} / \mathrm{m}^{3}$. These systems were not cost-effective compared to molten salt transport or compared to natural gas or residual oil at medium to high fuel cost escalation rates (Ref. 11). However, a reduction in cost of a factor of two would make thermochemical transport systems cost-eifective.

Carbon monoxide has an energy density of $12.6 \mathrm{MJ} / \mathrm{m}^{3}$, which is a factor of 4.3 to 4.6 higher that the systems previously studied. Furthermore, carbon monoxide transport would potentially require lower capital investment compared to the other systems studied because the exothermic portion of the chemical plant is eliminated and only a one-way pipeline is required, as compared to a two-way pipeline for closed-loop systems. Finally, very high temperatures (above $1500^{\circ} \mathrm{C}$ ) are available from the combustion of carbon monoxide.

The generic chemical heat pump system under stidy is shown in Fig. 2. This system can be used for either storing or transporting solar energy. iVe are initially investigating simple hydration reactions; e.g., solution of hydroxides in water. Heat is generated by mixing hot anhydrous hydroxide with steam under vacuum conditions (1). The heat of hydration causes an adiabatic temperature rise followed by heat removal to the industrial user (2). The reactor would contain an adiabatic section (a mixing tee followed by an insulated section of pipe) followed by a cooled section (a counter-current heat exchanger). The user heat transfer fluid is heated in the heat exchanger. 


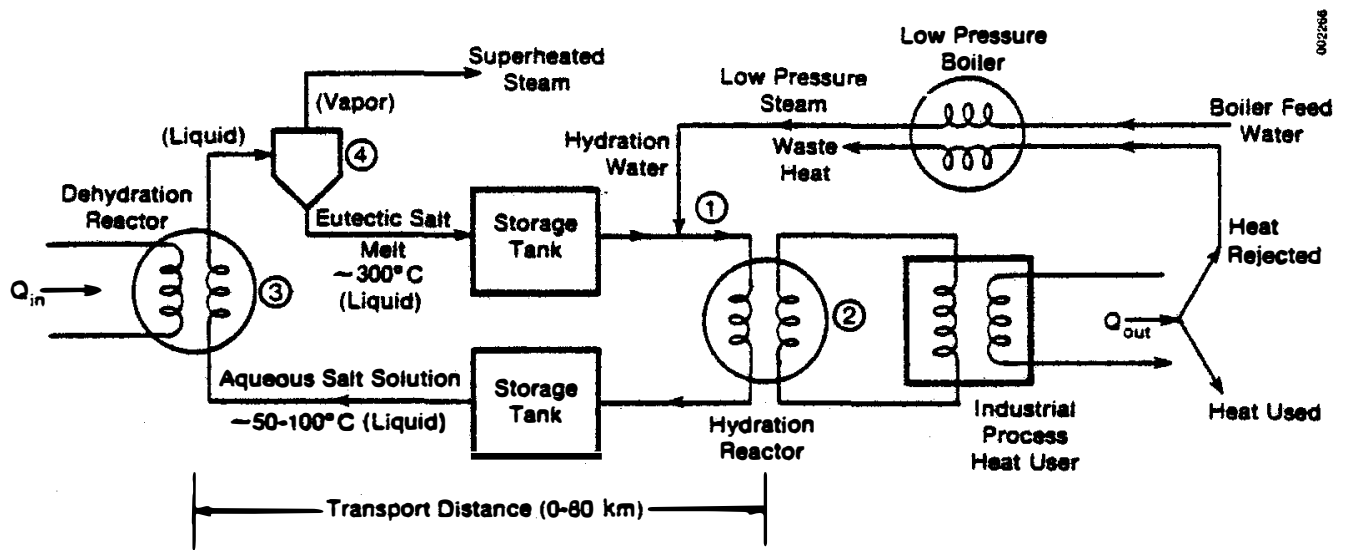

Fig. 2. Generic Beat Pump, Thermochemical Bnergy Storege and Trensport System

The reactor heat generation is caused by three effects: (1) the heat generated by hydrating the hydroxides, (2) the sensible heat from cooling the hydroxides, and (3) the latent heat of condensetion of the steam used to hydrate the hydroxide.

The maximum achievable temperature depends on the hydroxide-to-water ratio and the allowable vapor pressure of the hydroxide solution. If the reactor pressure is sufficiently low, the water of hydration can be supplied as steam, with the latent heat of vaporization extracted from the ambient or from process reject heat, giving a heat pumping effect. The resulting cold (below $100 \mathrm{C}$ ) hydroxide solution is transported back to a solar central receiver for dehydration (3) to produce superheated steam (-). The resulting hot enhydrous salt is then recycled.

Such a heat pump system has high energy densities $\left(1.8-2.2 \mathrm{GJ} / \mathrm{m}^{3}\right)$, since the system is liquid rather than gaseous, low cepital costs, since the reactors are simple heat exchangers and the liquid system requires small equipment; very high thermal efficiencies, in excess of $100 \%$ when the heat pumping effect is included and significantly higher delivery temperatures (up to $500 \mathrm{C}$ ) than molten salt temperatures because of the initial adiabatic hydration followed by heat removal in a counter-flow mode.

\section{CONCLUSTONS}

The storage technologies having the highest value-to-cost ratios are very high temperature molten salt, draw salt/air-rock, and metal/phese-chenge salt.

The major emphasis in 1983 for research in the very high temperature molten salt technology will be to complete the floeting platform stability tests, complete materials compatibility testing, and design the internal tank insulation. For molten nitrate salt, work will include direct-contact heat transfer measurements in a packed column and design of lower-pressure-drop packings. For the metal/phase-change-salt system, direct-contact heat transfer measurements will also be made.

For the molten slag technology, research on appropriate solar central receivers is required to assess the economic potential of the overall system. Then, further work to reduce the storage cost may be appropriate.

Continuing work on the phase-change salt/ceramic pellet storage concept is presently planned, but not under sponsorship of the Solar Energy Research Insti tute.

\section{RERBRENCES}

1. Copeland, R. J.: "Preliminary requirements for thermal storage subsystems in solar thermal applications". SERI/RR-731-264, Golden, Colorado, Solar Energy Research Institute, Apr. 1980.

2. Hock, S. M. and Karpuk, M. E.: "The value of thermal storage in solar industrial process heat systems'. SERI/TR-731-905, Golden, Colorado, Solar Energy Research Institute, Dec. 1980.

3. Dubberly, L. J. et al.: "Cost and performance of thermal storage concepts in solar thermal systems. Phase l: Water/Steam, Organic Fluid, and Closed Air Brayton Receiver, and Phase 2: Liquid Metal Receivers". Denver, Colorado, Stearns-Roger Services, Inc., Nov. and Dec. 1981. 
4. Copeland, R. J. et alo: "High temperature molten salt thermal systems". Proc. 17 th Intersociety Energy Conversion Engineering Conf erence (Los Angeles, California: August 8-12, 1982) Piscataway, New Jersey, Institute of Electrical and Electronics Engineers, 1982, Vol. 4, pp. 2032-6.

5. Copeland, R. J.: "Advanced, high-temperature molten salt storage". In: Proc. DOE Physical and Chemical Storage Annual Contractors' Review Meeting (Arlington, Virginia: Aug. 23-26, 1982) Washington, D.C., Department of Energy.

6. Bruckner, A. P. and Herzberg, A.: "High temperature integrated thermal energy storage system for solar thermal applications". SERI/STR-231-1812, a subcontract report by the Univer sity of Washington, Golden, Colorado, Solar Energy Research Institute, Dec. 1982.

7. Gross, R. J.: "Summary report of the study of single-mectium thermocline thermal energy storage". In: Proc. DOE Physical and Chemical Storage Annual Contractors' Review Meeting (Arlington, Virginia: Aug. 23-26, 1982) Washington, D.C., U.S. Department of Energy.

8. Wright, J. and d'Agincourt, C.: "Direct-contact air/molten salt heat exchange for solar thermal systems". Proc. 17th Intersociety Energy Conversion Engineering Conference (Los Angeles, California: August 8-12, 1982) Piscataway, New Jersey, Institute of Electrical and Electronics Engineers, Vol. 3, Pp. 1492-7.

9. Wright, J. E. and Bohn, M. S.: "Direct-contact thermal storage research". In: Proc. DOE Physical and Chemical Storage Annual Contractors' Review Meeting (Arlington, Virginia: Aug. 23-26, 1982) Washingtion, D.C., U.S. Department of Energy.

10. Claar, T. D. et al.: New thermal energy storage concepts for solar thermal applications". SERI/STR-23l-1860, a subcontract report by the Institute for Gas Technology, Golden, Colorado, Solar Energy Research Institute.

11. Nix, R. G.: "Feasibility of thermochemical energy storage and transport". SERI/TR-234-1655, Golden, Colorado, Solar Energy Research Institute, 1983. 